\title{
Deterioration of Groundwater in Beirut Due to Seawater Intrusion
}

\author{
Mark Saadeh1, Elie Wakim² \\ ${ }^{1}$ RWTH University, Aachen, Germany \\ ${ }^{2}$ American University of Technology (AUT), Halat, Lebanon \\ Email: saadeh_mark@yahoo.com, elie.wakim95@gmail.com
}

How to cite this paper: Saadeh, M. and Wakim, E. (2017) Deterioration of Groundwater in Beirut Due to Seawater Intrusion. Journal of Geoscience and Environment Protection, 5, 149-159.

https://doi.org/10.4236/gep.2017.511011

Received: September 20, 2017

Accepted: November 14, 2017

Published: November 17, 2017

Copyright ( 92017 by authors and Scientific Research Publishing Inc. This work is licensed under the Creative Commons Attribution International License (CC BY 4.0).

http://creativecommons.org/licenses/by/4.0/

(c) (i) Open Access

\begin{abstract}
All of Lebanon's aquifers, without exception, are afflicted with some form of contamination, be it from untreated raw sewage, pesticides or fertilizers, but at the forefront there is seawater intrusion, and nowhere it is more pronounced than in Beirut, the capital. Extensive sampling of Beirut's groundwater in recent years has revealed alarming values of Total Dissolved Solids (TDS) in the thousands of milligrams per litre, in an increasing number of wells. This irreversible deterioration of groundwater quality is forcing citizens to install costly desalination equipment, importing questionable water by private tankers or abandoning their wells altogether. Initial groundwater sampling began in 2004. In what was possibly Lebanon's worst drought in decades, another campaign to sample Beirut's groundwater was undertaken in the summer of 2014 which still continues to date. Acute water shortages in recent years coupled with recurrent periods of drought, have rendered Total Dissolved Solids (TDS) of many sampled wells in Beirut, equivalent to that of seawater $(\sim 37,500 \mathrm{mg} / \mathrm{L})$. Fundamental in combating the impact of seawater intrusion however is an understanding of the Ghyben-Herzberg principle which warns that for every meter of groundwater drop above sea level there is an equivalent rise of 40 meters of the saline-fresh water interface, demonstrating just how sensitive over-pumping is in coastal aquifers. With an understanding of the principle dynamics behind the phenomena of seawater intrusion, myriad methods may then be employed to combat this encroachment in coastal aquifers. Restricting or even preventing altogether withdrawals from Beirut's coastal aquifers may however be the only viable option left.
\end{abstract}

\section{Keywords}

Seawater Intrusion, Groundwater Footprint, Groundwater Protection Zones, Aquifer Storage Recovery, Total Dissolved Solids 


\section{Introduction}

Lebanon's groundwater is contaminated by myriad sources, but none rivals that of seawater intrusion when it comes to the coastal aquifers of Beirut. Additionally, raw sewage compounds the problem in the heavily populated cities of Beirut, Tripoli and Sidon [1] with an estimated well density exceeding 375 per square kilometer [2]. This concurrent deterioration of groundwater has gone unchecked for decades on end. Although contamination differs from pollution in that the latter constitutes an additional health threat [3], in this study they will be used interchangeably.

Normally, seawater intrusion occurs in unconfined and confined coastal aquifers whenever the water table or piezometric head is inadvertently lowered through excessive pumping. These coastal aquifers usually support large city populations where withdrawals from these aquifers often exceed recharge during the rainy season as has become the case for Beirut and its southern suburbs [4]. This can cause lateral intrusion (from the ocean due to excessive water withdrawals from coastal aquifers) as well as upcoming (from deeper seawater to pumping wells). The encroaching seawater will encounter an area known as the zone of dispersion, where the freshwater and seawater mix and form a broad interface. This interface moves back and forth naturally with the passing of seasons.

In recent years, an unhindered influx of Syrian refugees, topped with recurrent periods of drought has placed tremendous stress on already dwindling groundwater resources. These concurrent tensors have led to seawater replacing fresh groundwater in many wells of Beirut.

In light of any permanent and comprehensive monitoring network for groundwater, aquifers of Lebanon still require a great deal of insight. It is imperative to start with the basics and that would be to delineate clearly the hydraulic parameters of all aquifers through meticulous aquifer tests. Only then, can water experts begin to estimate sustainable yield in order to determine the allowable groundwater abstraction rates without incurring any long term damage to the quantity or quality of aquifer water as well as the hydraulically connected overlying ecosystems.

Some water experts continue to confuse safe with sustainable yield when addressing the maximum amount of water that can be safely withdrawn (or abstracted) from aquifers.

Safe yield is defined as the amount of water abstracted from an aquifer without exceeding its recharge, sustainable yield however takes into account the overlying basin or watershed by equating sustainable yield with a sliding fraction of the safe yield, often regarded in the whereabouts of $10 \%$ of an aquifer's recharge [5].

Not unlike other countries afflicted with seawater intrusion, a comprehensive monitoring program should be emplaced along the coastal cities of Lebanon to continuously map said encroachment and deal with aquifers afflicted with ever rising TDS values.

To that end, monitoring wells and piezometers further inland should also be 
emplaced to sample groundwater for other pollutants as well, namely from unregulated and untreated wastewater discharge [6].

\section{Materials and Methods}

Initial sampling and testing of groundwater began in 2004 (Figure 1) then again during the summer of 2014 (Figure 2) in Greater Beirut. Nearly a third of Lebanon's total population of about six million currently live in Beirut which has a



Figure 1. Initial sampling of Beirut wells in 2004. 


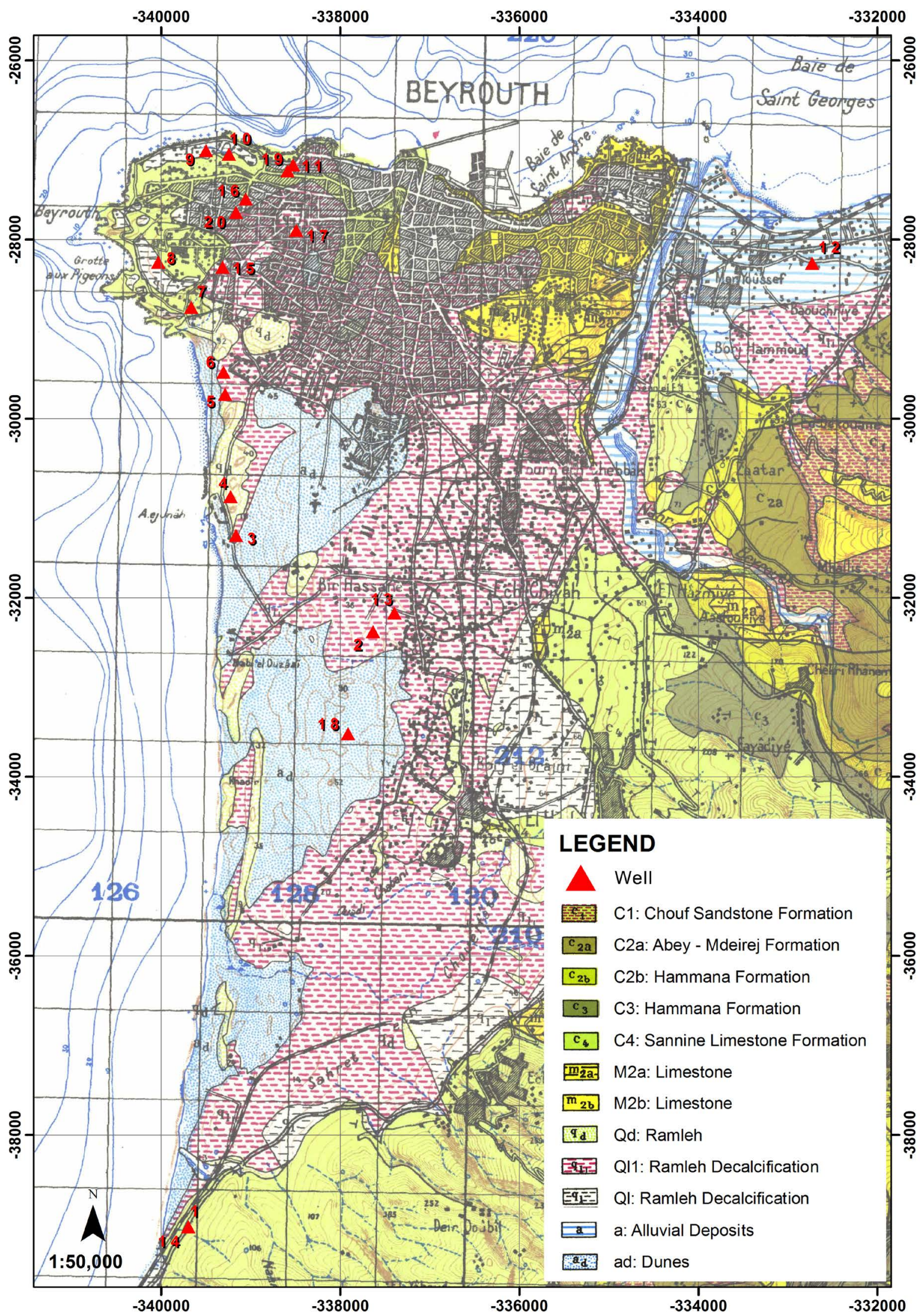

Figure 2. Sampled wells of Beirut in 2014. 
surface area of approximately $130 \mathrm{~km}^{2}$ [7], circumscribed by the Kalb River to the north, Damour River to the South, and the Lebanon Mountain range to the east.

Tests were carried out in accordance with ASTM, 2001 guidelines, D4449-01 Standard Guide for Sampling Groundwater Monitoring Wells. The test results of the two summer campaigns are summarized on page nine.

Water wells were analyzed on site for $\mathrm{pH}$ and Total Dissolved Solids (TDS), thus minimizing any errors imparted by transporting samples to laboratories. TDS is used interchangeably with salinity in this article for the sake of simplicity. The various parameters were analyzed using standard procedures in accordance to "The Standard Methods for the Examination of Water and Wastewater" [8]. TDS and $\mathrm{pH}$ were measured using individually calibrated portable testers (LaMotte, USA).

Over twenty wells were monitored monthly in Beirut in 2004 (Figure 1), then again during the summer of 2014 (Figure 2). The sampled wells were first purged before taking in-situ TDS measurements usually within 15 minutes. In one instance however, well \#20 was allowed to run for a few hours. In the first half hour, a TDS reading of $22,000 \mathrm{mg} / \mathrm{L}$ was recorded, then upon termination, the TDS had risen to over $30,000 \mathrm{mg} / \mathrm{L}$, nearing that of seawater composition.

The results were evaluated in accordance with the Lebanese Bottled Water Guidelines [9]; and the World Health Organization (WHO) Guidelines for Drinking Water Quality [10]. ESRI's ArcGIS 9.3 was used to generate the geological figures in the study area. Note that every square in the figure is equivalent to one square kilometre. All the wells that were sampled in Figure 1, are alpha numerically numbered either with the letter $\mathrm{P}$ (for private wells) or G (for government wells).

\section{Results and Discussion}

To understand the aquifers and aquitards in and around Beirut, the hydrostratigraphic units of are briefly summarized in Table 1 . The terms, aquifer and aquitards are relativistic terms and preferred to the terms aquiclude and aquifuge which have fallen out of use [11].

The aquifers of Beirut most vulnerable to seawater intrusion include the coastal Sannine $\left(\mathrm{C}_{4}\right)$ limestone formation as well as the Quaternary (q) alluvial deposits.

Seawater would render groundwater in these aquifers unsuitable for public supply with only a $2 \%$ contamination [2]. Normally, a $1 \%$ mixing would triple groundwater salinity or TDS, while $5 \%$ mixing would increase salinity to roughly $4500 \mathrm{mg} / \mathrm{L}$ [12]. Hence once freshwater resources are degraded by salt contamination, it will take a very long time for aquifers to recover, and if positive groundwater recharge conditions are not re-established, they may never recover [13].

The TDS measurements, especially of Well \#20 clearly indicate a trend steadily increasing over the years reaching concentrations equivalent to that of 
Table 1. Hydrostratigraphic units of Beirut \& suburbs.

\begin{tabular}{|c|c|c|c|c|}
\hline Period/Epoch & Sratigraphic Unit & Hydraulic Unit & Lithology & Thickness \\
\hline Quaternary & Undefined (q) & Aquifer & Alluvial deposits & Up to $200 \mathrm{~m}$ \\
\hline Tertiary/Pliocene & Undefined (p) & Aquitard & Marl, conglomerate, basalt & Up to $500 \mathrm{~m}$ \\
\hline Tertiary/Miocene & Undefined (m) & Aquifer & Marl & Up to $300 \mathrm{~m}$ \\
\hline Tertiary/Eocene & Undefined (e) & Aquifer & Marly limestone & Up to $800 \mathrm{~m}$ \\
\hline Cretaceous/Senonian & Chekka formation $\left(\mathrm{C}_{6}\right)$ & Aquitard & Chalk & $100-500 m$ \\
\hline Cretaceous/Turonian & Maameltein formation $\left(C_{5}\right)$ & Aquifer & Marly limestone & $200-300 \mathrm{~m}$ \\
\hline Cretaceous/Cenomanian & Sannine formation $\left(\mathrm{C}_{4}\right)$ & Major aquifer & Dolomitic limestone & Up to $800 \mathrm{~m}$ \\
\hline Cretaceous/Albian & Hammana formation $\left(\mathrm{C}_{3}\right)$ & Aquitard & Marly limestone & Up to $400 \mathrm{~m}$ \\
\hline Cretaceous/Upper Aptian & Mdeirij formation $\left(\mathrm{C}_{2 \mathrm{~b}}\right)$ & Aquifer & Dolomitic limestone & Up to $50 \mathrm{~m}$ \\
\hline Cretaceous/Lower Aptian & Abeih formation $\left(\mathrm{C}_{2 \mathrm{a}}\right)$ & Aquitard & Clayey limestone & $80-170 m$ \\
\hline Cretaceous/Neocomian & Chouf formation $\left(C_{1}\right)$ & Aquifer & Sandstone & $10-300 \mathrm{~m}$ \\
\hline Jurassic/Portlandian & Salima formation $\left(\mathrm{J}_{7}\right)$ & Aquitard & Marly limestone & Up to $180 \mathrm{~m}$ \\
\hline Jurassic/Kimmeridgian & Bikfaya formation $\left(\mathrm{J}_{6}\right)$ & Major aquifer & Dolomitic limestone & Up to $80 \mathrm{~m}$ \\
\hline Jurassic/Oxfordian & Bhannes formation $\left(\mathrm{J}_{5}\right)$ & Aquitard & Marly limestone & Up to $150 \mathrm{~m}$ \\
\hline Jurassic/Callovian & Keserwan formation $\left(\mathrm{J}_{4}\right)$ & Major aquifer & Dolomitic limestone & Exceeding $1000 \mathrm{~m}$ \\
\hline
\end{tabular}

seawater in an increasing number of wells. The question however, whether the rise in groundwater salinity is due to seawater or other sources of salts has been satisfactorily addressed in numerous studies, by Saadeh in 2008 [14], then again Jurdi in 2010 [15]. It could be suggested that in the span of nearly 10 years, there is nearly a 23 fold increase in groundwater salinity (TDS) in the densely populated southern suburbs of Beirut (Figure 3).

Although the World Health Organization guidelines for drinking water [11] do not express any health hazard from increased TDS concentrations, the economic impact of saline groundwater on Beirut's infrastructure is incalculable.

The wells most severely affected by seawater intrusion are unsurprisingly located in the densely populated southern suburbs of Beirut. Most notable of the wells sampled in the summer of 2014, is \#13 (Table 2) where TDS is equivalent to that of the Mediterranean Sea composition of 37,500 mg/L. Well \#18, also in the southern suburbs of Beirut, further attests to the severity of seawater intrusion.

Other severely affected wells include \#19 and \#20 located in what is referred to as Ras Beirut. Their values of 23,000 and 24,200 mg/L respectively indicate nearly a six-fold increase in groundwater salinity in just under ten years between 2004 and 2014.

Once seawater has encroached so severely upon aquifers, not unlike those of Beirut, reversing the effects even through what is often referred to as Aquifer Storage Recovery (ASR), may take decades to undo, according to many studies including Bear in 1999 [12], then again Barlow in 2003 [2]. Even though, Aquifer 


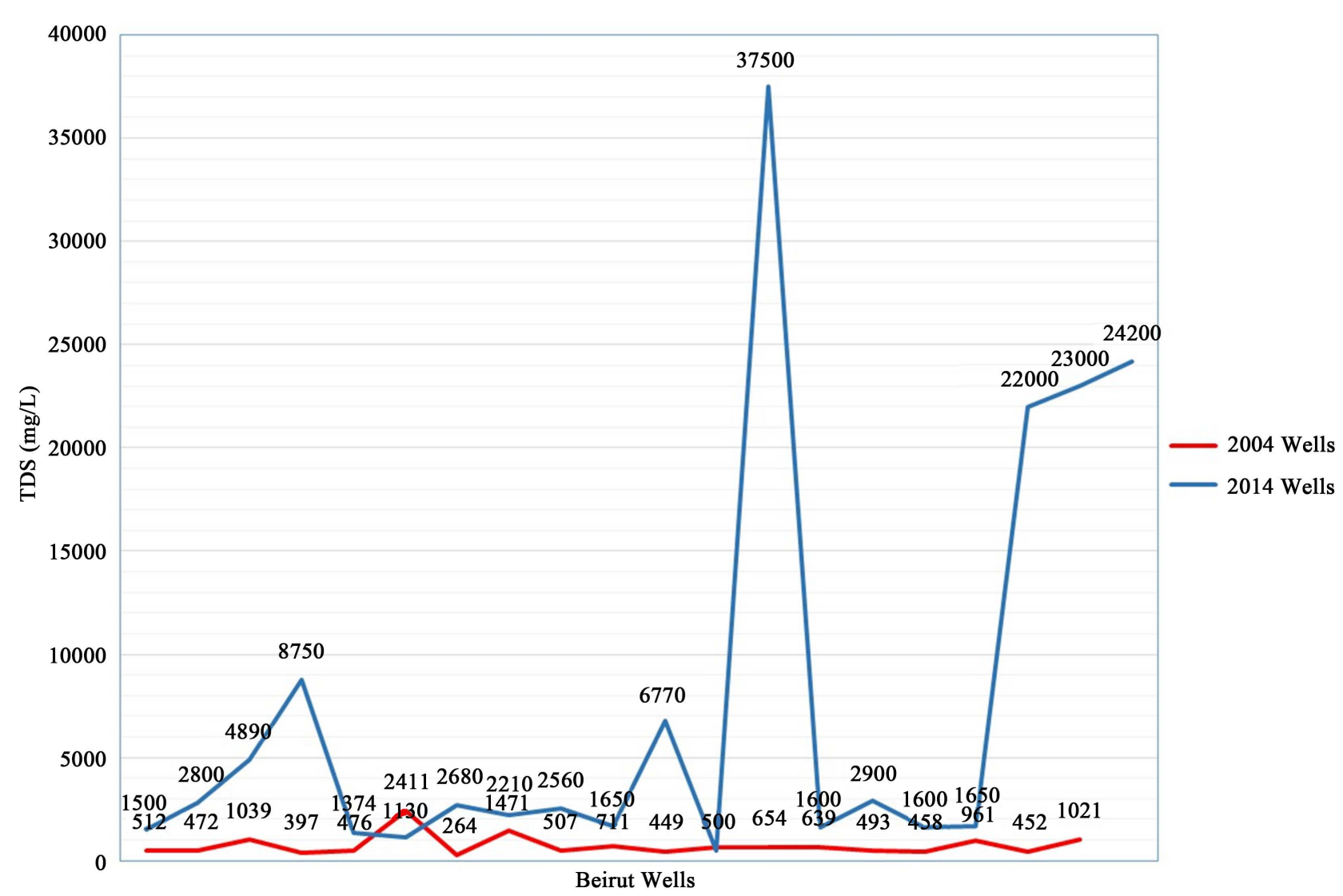

Figure 3. Comparative analysis of TDS of Beirut wells in 2004 and 2014.

Table 2. Sampled Beirut wells (2004 \& 2014).

\begin{tabular}{cccc}
\hline 2004 Wells & TDS (mg/L) & TDS (mg/L) \\
\hline G6 & 512 & 1 & 1500 \\
G5 & 472 & 2 & 2800 \\
G2 & 1039 & 3 & 4890 \\
G4 & 397 & 4 & 8750 \\
G9 & 476 & 5 & 1374 \\
P10 & 2411 & 6 & 1130 \\
P4 & 264 & 7 & 2680 \\
P5 & 1471 & $\mathbf{5}$ & 2210 \\
G8 & 507 & 9 & 2560 \\
G10 & 711 & $\mathbf{8}$ & 1650 \\
G7 & 449 & 10 & 6770 \\
P2 & 633 & 11 & 500 \\
P3 & 654 & 12 & 37,500 \\
G1 & 639 & 13 & 1600 \\
P6 & 493 & 14 & 2900 \\
P7 & 458 & 15 & 1600 \\
P8 & 961 & 16 & 1650 \\
P9 & 452 & 17 & 22,000 \\
P1 & 1021 & 18 & 23,000
\end{tabular}


Storage Recovery or ASR is often employed for coastal aquifers around the world, only potable water standards should provide a reference point for recharge water quality [16].

The quality of recharge water is in fact a major hindrance to current ASR projects in Beirut, since often enough untreated surface runoff becomes a poor substitute for clean freshwater, only compounding the problem of aquifer contamination.

\section{Conclusions}

The results of the initial study in 2004, then again in 2014, reflect the deleterious effect that seawater intrusion has claimed on the coastal aquifers of Beirut and suburbs. Hence, this study emphasizes the need for an immediate implementation of a comprehensive integrated water resources management plan (IWRM).

Water management strategies are by no means a one size fits all approach, and each has to be tuned to its unique set of inherent goals, but the aforementioned is at the very least a step in the right direction.

Tony Allan warns that "wherever we irrigate, society always runs out of water" [17]. Lebanon, and the Middle East continues with its heavy reliance on irrigation consuming $70 \%$ of its renewable fresh water resources [6].

If an improvement of only $10 \%$ in agricultural efficiency were to be achieved, that could potentially double the resources available for public water supply [18].

\section{Recommendations}

\subsection{Buffer Zone}

Any abstraction within $400 \mathrm{~m}$ from the coast line with an abstraction rate of just $2 \mathrm{~L} / \mathrm{s}$ can induce seawater intrusion and thus groundwater abstraction from wells existing in this coastal strip should be strictly prohibited, whereas in the range of $1300 \mathrm{~m}$ away from the coast line pumping operation of $3 \mathrm{~L} / \mathrm{s}$ are considered safe [19].

It follows, that a moratorium on groundwater abstraction must be immediately implemented in the shape of a buffer zone along the entire coastline of Beirut. The aquifers must be allowed to recharge naturally and if possibly artificially, most likely exceeding 20 years

Concurrently, the following recommendations could be implemented for the other coastal cities of Lebanon, lest they meet the same fate as Beirut. These tried and tested management strategies would preserve and even improve the quality and quantity of groundwater as well as overlying water basins, in what is commonly referred to as integrated water resources management (IWRM)

\subsection{Groundwater Footprint}

Among the myriad strategies to groundwater management, fundamental is the seminal approach of "groundwater footprint" introduced by Gleeson [20] which assesses groundwater abstraction rates for individual aquifers. Succinctly defined, 
groundwater footprint (GF) is the area required to sustain groundwater use and ecosystems overlying an aquifer. Gleeson calculates said footprint using the following formula:

$$
\mathrm{GF}=A[C /(R-E)]
$$

where, $C$ the average annual abstraction of groundwater, $R$ the recharge rate, and $E$ the groundwater that needs to be allocated to surface water flow to sustain ecosystems. $A$ is the areal extent of any region of interest where aquifer inflows $(R)$ and outflows ( $C$ and $E$ ) can be defined.

Once the groundwater footprint (GF) is calculated for any aquifer, the ratio of GF to the actual aquifer area (AA) becomes an important indicator of groundwater stress.

For instance, a GF/AA ratio greater than one indicates unsustainable groundwater consumption. On the other hand, a ratio of less than one suggests that the groundwater is not being depleted at the present [20].

Of Lebanon's fifteen hydrostratigraphic units mentioned in Table 1, all nine aquifers should be assessed using the "groundwater footprint" method in order to determine the degree to which they are being depleted. For those aquifers that still stand a chance of avoiding the same fate as Beirut's aquifers, sustainable yield may then come into play.

\subsection{Water Metering}

Once aquifers are assessed for their sustainable yield and water quality, abstracted well water must then be accounted for be it in the public, industrial or agricultural sector, through reliable water metering.

Lebanon adamantly remains obstinate to water metering on a national scale for myriad reasons [15]. As such, estimates differ as to the exact amount of water losses, whether real or apparent, but most water experts would agree that those losses are staggering, and mostly attributed to leakages from decrepit networks coupled with illegal tapping.

Tariffs on this most contentious resource however still remain fixed at a flat rate. Any attempt to install water meters, have been often been derailed. Metering is nevertheless critical since it has been demonstrated that metered cities consume at the very least $15 \%$ less water than their unmetered counter- parts [18].

\subsection{Groundwater Protection}

To manage Lebanon's groundwater, it is important to delineate groundwater protection zones. Within these water protection zones, water resources take priority over all other competing interests of land use.

A typical area where groundwater would be protected against contamination may be divided into three zones as is common practice in Germany [21]:

1) Protection Zone I: protects the direct vicinity of a wells or springs against any form of contamination. Said wells and springs would be encircled by fences 
with a radius of tens of meters preventing any unauthorized entry and any form of agriculture or construction.

2) Protection Zone II: categorized as zones vast enough to eliminate microorganisms introduced into the groundwater after 50 days. The "50-day-line" is the connection of all sites within an aquifer from which the groundwater needs to be held for 50 days until it arrives at a well or spring.

3) Protection Zone III: in this protected zone, most if not all sources of pollution are forbidden whether from the agricultural, industrial or domestic sector.

\section{Acknowledgements}

This study took several years of effort and countless long hours to bring to fruition, which would not have been possible without the unwavering help of my friends and colleagues, Mr. Elie Wakim and Mr. Ali Koumaiha.

\section{References}

[1] ECODIT (2010) State and Trends of the Lebanese Environment, 355 p.

[2] Barlow, P. (2003) Groundwater in Freshwater-Seawater Environments of the Atlantic Coast. Technical Report, USGS, Reston.

[3] VanLoon, G. and Duffy, S. (2005) Environmental Chemistry: A Global Perspective. Oxford University Press, Oxford, $515 \mathrm{p}$.

[4] Moujabber, M., et al. (2006) Comparison of Different Indicators for Groundwater Contamination by Seawater Intrusion on the Lebanese Coast. Water Resources Management, 20, 161-180. https://doi.org/10.1007/s11269-006-7376-4

[5] Ponce, V.M. (2007) Sustainable Yield of Groundwater. http://gwsustainability.sdsu.edu/

[6] Alieh, Y. (2014) Water-The Glass Is Half Full. Lebanon Opportunities, Issue 26, 32-47.

[7] Ukayli, M. (2006) Hydrogeology of Beirut and Vicinity. Master's Thesis, American University of Beirut, Beirut.

[8] American Public Health Association, American Water Works Association, \& Water Environment Federation (2010) Standard Methods for the Examination of Water and Wastewater. 21st Edition, American Public Health Association, Washington, DC.

[9] Lebanese Standards Institution (LIBNOR) (1999) Lebanese Standard No 162:1999: “Bottled Drinking Water." LIBNOR, Beirut.

[10] World Health Organization (WHO) (2006) Guidelines for Drinking Water Quality. 3rd Edition, Geneva. http://www.who.int/water_sanitation_health

[11] Fitts, C. (2002) Groundwater Science. Academic Press of Elsevier, 450 p.

[12] Bear, J. (1999) Seawater Intrusion in Coastal Aquifers: Concepts, Methods and Practices. Kluwer Academic Publishers, Dordrecht.

https://doi.org/10.1007/978-94-017-2969-7

[13] Pepper, I., et al. (2006) Environmental and Pollution Science. Academic Press of Elsevier, Cambridge, Massachusetts, $532 \mathrm{p}$.

[14] Saadeh, M. (2008) Seawater Intrusion in Greater Beirut, Lebanon, Climatic Changes and Water Resources in the Middle East and North Africa, Environmental Science and Engineering. Springer, Berlin. 
[15] Jurdi, M. and Korfali, S. (2010) Deterioration of Coastal Water Aquifers: Causes and Impacts. European Water, 29, 3-10.

[16] Pyne, D. (1995) Groundwater Recharge and Wells: A Guide to Aquifer Storage Recovery. Lewis Publishers, Florida, 376 p.

[17] Allan, T. (2011) Virtual Water. I.B. Tauris, London, 350 p.

[18] Ratnayaka, D., et al. (2009) TWORT’s Water Supply. Elsevier, Amsterdam, 711 p.

[19] Hdeib, R. (2012) Seawater Intrusion at the Lebanese Coastal Aquifers Khalde-Jiyeh Case Study. Thesis, Lebanese University, Beirut.

[20] Gleeson, T., et al. (2012) Water Balance of Global Aquifers Revealed by Groundwater Footprint. Nature, 488, 97-200. https://doi.org/10.1038/nature11295

[21] Balke, K., et al. (2008) Groundwater Protection: "What Can We Learn from Germany?” Journal of Zhejiang University Science, 9, 227-231.

https://doi.org/10.1631/jzus.B0710639 